\title{
High-Temperature Corrosion Behavior of Al-Coated Ni-Base Alloys in Lithium Molten Salt for Electroreduction
}

\author{
Wan-Bae Kim ${ }^{1}{ }^{1}$, Woo-Seok Choi $^{1}$, Kyu-Seok Lim ${ }^{1}$, Soo-Haeng Cho ${ }^{2}$ and Jong-Hyeon Lee ${ }^{1,2,3, * \mathbb{C}}$ \\ 1 Department of Materials Science and Engineering, Chungnam National University, Daejeon 34134, Korea; \\ dhksqo07@cnu.ac.kr (W.-B.K.); chldntjr1213@naver.com (W.-S.C.); spion92@daum.net (K.-S.L.) \\ 2 Rapidly Solidified Materials Research Center (RASOM), Chungnam National University, \\ Daejeon 34134, Korea; chosoo-haeng@cnu.ac.kr \\ 3 Graduate School of Energy Science and Technology, Chungnam National University, Daejeon 34134, Korea \\ * Correspondence: jonglee@cnu.ac.kr; Tel.: +82-42-821-6596; Fax: +82-42-822-5850
}

Citation: Kim, W.-B.; Choi, W.-S.; Lim, K.-S.; Cho, S.-H.; Lee, J.-H High-Temperature Corrosion Behavior of Al-Coated Ni-Base Alloys in Lithium Molten Salt for Electroreduction. Coatings 2021, 11, 328. https://doi.org/10.3390/ coatings 11030328

Academic Editor: Luigi Calabrese

Received: 29 January 2021

Accepted: 8 March 2021

Published: 13 March 2021

Publisher's Note: MDPI stays neutral with regard to jurisdictional claims in published maps and institutional affiliations.

Copyright: (c) 2021 by the authors. Licensee MDPI, Basel, Switzerland. This article is an open access article distributed under the terms and conditions of the Creative Commons Attribution (CC BY) license (https:// creativecommons.org/licenses/by/ $4.0 /)$.

\begin{abstract}
The electrolytic reduction of a spent oxide fuel involves the liberation of oxygen in a molten salt $\mathrm{LiCl}-\mathrm{Li}_{2} \mathrm{O}$ electrolyte, which creates a corrosive environment for typical structural materials. In this study, the corrosion behaviors of Al-Y-coated specimens in a Li molten salt kept under an oxidizing atmosphere at $650{ }^{\circ} \mathrm{C}$ for 72 and $168 \mathrm{~h}$ were investigated. The weight loss fraction of the coated specimen to bare specimen was approximately $60 \%$ for $3 \% \mathrm{Li}_{2} \mathrm{O}$ and $54 \%$ for $8 \% \mathrm{Li}_{2} \mathrm{O}$ at $72 \mathrm{~h}$, and approximately $38 \%$ for $3 \% \mathrm{Li}_{2} \mathrm{O}$ and $30 \%$ for $8 \% \mathrm{Li}_{2} \mathrm{O}$ at $168 \mathrm{~h}$. Corrosion was induced in the $\mathrm{LiCl}-\mathrm{Li}_{2} \mathrm{O}$ molten salt by the basic oxide ion $\mathrm{O}^{2-}$ via the basic flux mechanism, and the corrosion product was found to be dependent on the activity of the $\mathrm{O}^{2-}$ ion. The increase in weight loss may have been caused by the increase in the $\mathrm{O}^{2-}$ concentration due to the increase in the $\mathrm{Li}_{2} \mathrm{O}$ concentration rather than being because of the increased reaction time. The Al-Y coating was found to be beneficial for hot corrosion resistance, which can be useful for handling high-temperature lithium molten salt under an oxidizing atmosphere.
\end{abstract}

Keywords: high-temperature corrosion behavior; aluminum-yttrium coating; lithium molten salt; electrolytic reduction

\section{Introduction}

Molten salts are used in various industries due to their high electrical conductivity, high-density processing, and fluid properties. Recently, they have been attracting increasing attention for applications in jet engines [1-5], fuel cells [6-8], energy storage [9-11], and metal purifications [12-14]. However, molten salts corrode container materials and various components of electrolysis equipment. Hence, numerous studies have been conducted to understand the corrosion of the structural materials used for handling high-temperature molten salts, such as sulfates [15,16], carbonates [17,18], fluoride [19-21], and chloride systems [22,23]. Superalloys have been developed as a structural material for devices using high-temperature molten salts, and studies on their high-temperature corrosion characteristics are being continuously conducted [24-31]. However, according to previous studies, this type of alloy may not be able to simultaneously fulfil the criteria of high-temperature strength and corrosion resistance when placed in a high-temperature electrolyte containing oxygen and a strongly corrosive lithium molten salt $[12,31]$. Therefore, employing a coating that provides a thermal barrier has been found to be the most effective and economical method for enhancing the corrosion resistance. Coating technologies improve the surface characteristics of the base material with respect to its environment, and the use of these technologies has expanded with the improvement of coating material properties, such as high-temperature corrosion resistance [32-37], abrasion resistance [38,39], and electromagnetic properties $[40,41]$. Such surface-coating technologies offer the advantage 
of improving the high-temperature corrosion resistance of the base material without significantly affecting its mechanical properties. In general, Al-based oxides formed on the surface are stable at high temperatures, have a relatively slow growth rate, and improve corrosion resistance due to the dense structure. Therefore, research is being conducted to improve corrosion resistance at high temperatures by adding $\mathrm{Al}$ to the base metal or coating the surface. Recent reports have confirmed that Fe [42] and Ni alloys [43,44] can be used as inert anode materials in a high-temperature electrolyte by reacting the electrolyte with $\mathrm{Al}_{2} \mathrm{O}_{3}$ to form an $\mathrm{Al}_{2} \mathrm{O}_{3}$-based composite oxide passive film, thus securing long-term durability [45]. Furthermore, in some studies, $\mathrm{Al}$ has been supplied either as an alloying element or from an electrolyte to form an $\mathrm{Al}_{2} \mathrm{O}_{3}$ composite oxide layer. Therefore, in the absence of an $\mathrm{Al}$ source in the electrolyte or alloy, the possible applications of generalpurpose commercial alloys, for example, in high-temperature molten carbonate fuel cells (MCFCs), waste incineration systems, and molten salt electrolysis systems, can be greatly expanded if similar corrosion resistance is achieved by supplying Al through the surface treatment of the structural material.

The electrochemical reduction of spent oxide nuclear fuel is carried out in a hightemperature $\mathrm{LiCl}-\mathrm{Li}_{2} \mathrm{O}$ molten salt system, where the fuel reduces to $\mathrm{U}$ metal at the cathode, and $\mathrm{O}$ is generated at the anode. This electrolytic reduction process is carried out in a highly corrosive molten salt system at $650{ }^{\circ} \mathrm{C}$ or higher. Due to the oxidizing atmosphere formed by the generated $\mathrm{O}$, the molten salt-handling device is in a severely corrosive environment. Thus, a device material suitable for handling the molten salt, namely, an ordinary corrosionresistant structural material, must be developed for implementation in this electrochemical reduction technology. However, only a few studies have reported the corrosion resistance of Al-coated structural materials used in devices that handle high-temperature lithium molten salts, which is the subject of this study.

In this study, Haynes 263, which has an excellent strength, ductility, and weldability at high temperatures, was used as the Ni-based superalloy. The high-temperature corrosion behaviors of the Haynes 263 specimen coated with $\mathrm{Al}$ and $\mathrm{Y}$ were investigated using magnetron sputtering and electron beam physical vapor deposition (EB-PVD) in an oxygengenerating high-temperature Li molten salt system under simulated electrolytic reduction conditions.

\section{Materials and Methods}

\subsection{Preparation of Specimen}

The Ni-based superalloy Haynes 263 (Ni: 51.35, Cr: 20.0, Fe: 0.50, C: 0.05, Si: 0.13, Mn: 0.10, Mo: 5.80, Al: 0.45, Co: 19.20, and Ti: 2.39 wt.\%) was used as the base material. The specimen was heated and then water-cooled at $1050{ }^{\circ} \mathrm{C}$ for $1 \mathrm{~h}$ to remove internal defects and decompose carbides. A specimen $70 \mathrm{~mm}$ in length, $15 \mathrm{~mm}$ in width, and $70 \mathrm{~mm}$ thick was prepared and then heat-treated at $950{ }^{\circ} \mathrm{C}$ for $1 \mathrm{~h}$ for stabilization treatment. Before the corrosion test, the specimen was polished in one direction with 1200-grit SiC paper and then degreased with distilled water and acetone. Magnetron sputtering was performed to deposit a uniform Al-Y coating layer because it has high sputtering efficiency, reduces collisions with the specimens and thin films by the vortex motion of electrons, and has a constant deposition rate and uniform thickness at a given input power [39]. In addition, unlike in the conventional diffusion coating process, the microstructures of the deposited ceramics can be varied in EB-PVD by adjusting the deposition process parameters, such as the deposition rate, obtaining a coating layer with a uniform surface and good adhesion. Due to these features, magnetic sputtering and EB-PVD processes were used in this experiment.

\subsection{Coating Formulation}

A preliminary experiment using magnetron sputtering was conducted for the conditions where the $\mathrm{Al}$ coating exhibits optimal adhesion to the specimen. The initial vacuum degree was $133.322 \times 10^{-6} \mathrm{~Pa}$, the specimen temperature was $250{ }^{\circ} \mathrm{C}$, the electron beam 
power was $4 \mathrm{~kW}$, and the deposition rate was approximately $0.3 \mu \mathrm{m} / \mathrm{min}$. The thickness of the coating layer deposited by controlling the deposition time (35 min) was $10 \mu \mathrm{m}$. The EB-PVD coating conditions for the optimal adhesion of an $\mathrm{Y}$ coating on the deposited $\mathrm{Al}$ were also evaluated. The initial vacuum was $133.322 \times 10^{-5} \mathrm{~Pa}$, the electron beam power was $8 \mathrm{kV}(100-110 \mathrm{~mA})$, the specimen temperature was $400{ }^{\circ} \mathrm{C}$, and the deposition rate was approximately $1 \mathrm{~nm} / \mathrm{s}$. The thickness of the coating layer deposited by controlling the deposition time was $0.3 \mu \mathrm{m}$.

\subsection{High-Temperature Corrosion Tests}

The experimental apparatus consisted of a reactor and a mixed gas supply, as shown in Figure 1. A LiCl (Rare Metallic Co., Ltd., Tokyo, Japan, 99.9\%) and $\mathrm{Li}_{2} \mathrm{O}$ (Cerac, WI, USA, -100 mesh, 99.5\%) powder mixture and a thermocouple shielded with an $\mathrm{Al}_{2} \mathrm{O}_{3}$ tube were introduced into a high-density $\mathrm{MgO}$ crucible and then heated at $300{ }^{\circ} \mathrm{C}$ for $3 \mathrm{~h}$ in an $\mathrm{Ar}$ atmosphere to remove any moisture picked up. Subsequently, the specimens and $\mathrm{Al}_{2} \mathrm{O}_{3}$ tube were immersed into the molten salt, and mixed gas $\left(\mathrm{Ar}-10 \% \mathrm{O}_{2}\right)$ was supplied through an $\mathrm{Al}_{2} \mathrm{O}_{3}$ tube. Two $\mathrm{MgO}$ crucibles were used in the apparatus, as shown in Figure 1, and each crucible held one specimen. The corrosion test was conducted for the bare and coated specimens. For the bare specimens, the corrosion environment temperature was $650{ }^{\circ} \mathrm{C}$, the corrosion time was $24-168 \mathrm{~h}$, and the $\mathrm{Li}_{2} \mathrm{O}$ concentration was $1-5 \mathrm{wt} . \%$. For the coated specimens, the corrosion environment temperature was $650{ }^{\circ} \mathrm{C}$, the corrosion times were 72 and $168 \mathrm{~h}$, and the $\mathrm{Li}_{2} \mathrm{O}$ concentrations were 3 and 8 wt.\%. Following the corrosion tests, the specimens were separated from the molten salt and cooled to room temperature $\left(15-20^{\circ} \mathrm{C}\right)$ in an Ar atmosphere.

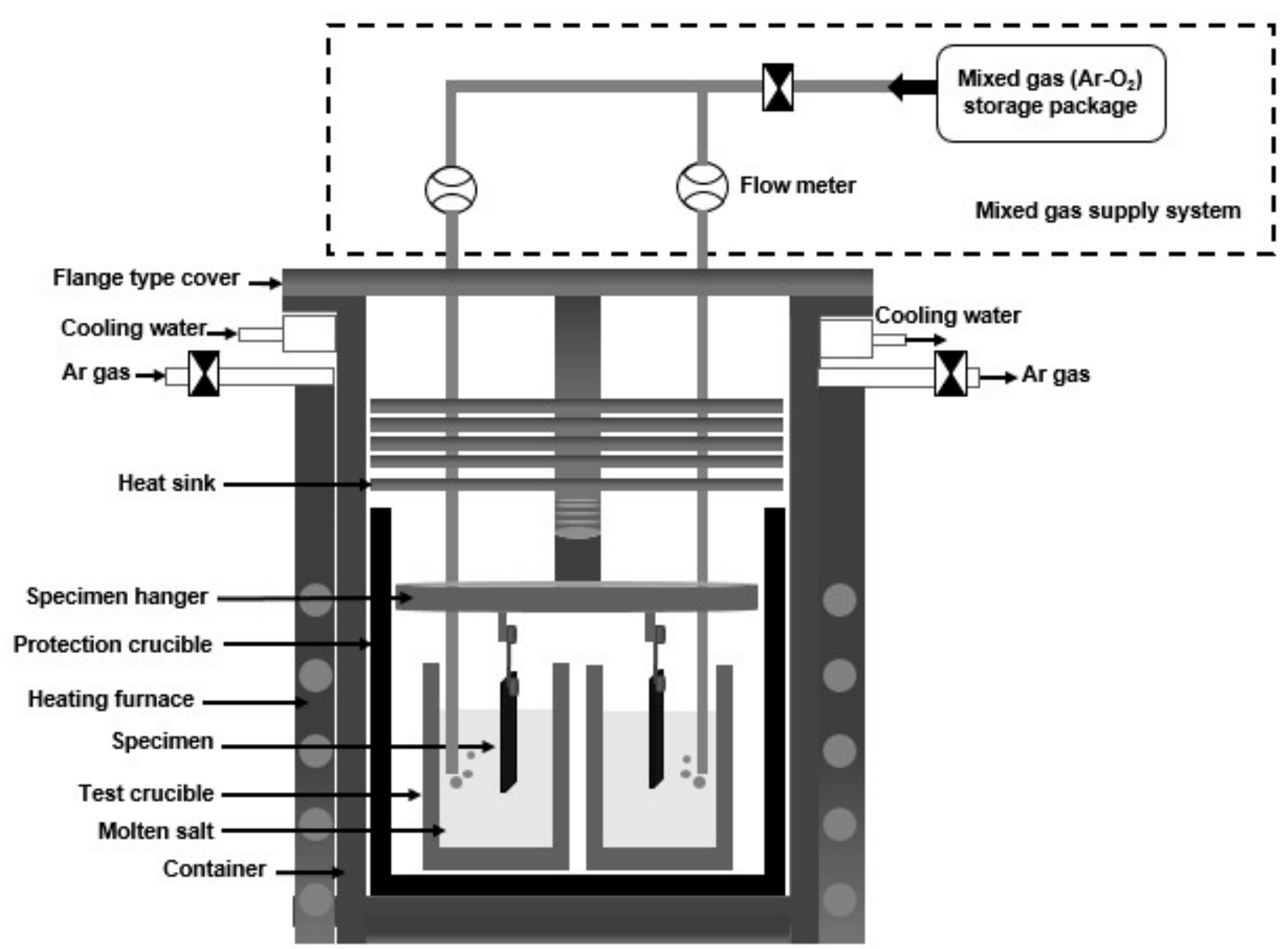

Figure 1. Schematic of corrosion test apparatus. 


\subsection{Characterization}

The reactor was opened, and the specimens were removed for a visual examination. The specimens were then cleaned ultrasonically in distilled water to remove the molten salt and dried for more than $24 \mathrm{~h}$ in a drying furnace at $80^{\circ} \mathrm{C}$. The initial and final weights of the tested specimens were then recorded to assess the extent of corrosion using an analytical balance (Sartorius QUINTIX224-1S, Goettingen, Germany). The corroded specimens were then cut using a diamond cutter and ultrasonically cleaned in acetone for characterization. Some of the specimens were then prepared for metallographic examination via cold mounting, grinding, and polishing. The microstructure, morphology, chemical composition, and elemental distribution of the corrosion layer and substrate were examined using a microscope for field emission-scanning electron microscopy (FE-SEM, JEOL, JSM-7000F, Tokyo, Japan) with apparatus equipped with a spectrometer for energy dispersive X-ray spectroscopy (EDS, JEOL, Tokyo, Japan) [46]. X-ray powder diffraction (XRD, D/MAX2200 Ultima/PC, Rigaku, Tokyo, Japan) analysis was used to determine the structure of the hot corrosion products using the standard method [47]. The following conditions were applied in the analyses: the FE-SEM/EDS applied voltage and vacuum pressure were $15 \mathrm{kV}$ and $7.04 \times 10^{-4} \mathrm{~Pa}$, respectively; the XRD scan rate, step, and half-width range (20) were $3.5^{\circ} / \mathrm{min}, 0.05^{\circ}$, and $15-100^{\circ}$, respectively.

\section{Results and Discussion}

\subsection{Corrosion Kinetics}

The weight loss of the bare (closed legends) and Al-coated (open legends) Haynes 263 specimens after the corrosion tests in the $\mathrm{LiCl}-(1,3,5$, and $8 \mathrm{wt} . \%) \mathrm{Li}_{2} \mathrm{O}$ molten salt as a function of time is shown in Figure 2. The bare specimens lost weight as the $\mathrm{Li}_{2} \mathrm{O}$ concentration increased, and the weight loss increased linearly with time, which suggests that the corrosion product formed a porous, nonprotective film. The formation of the porous film in the molten salt $\mathrm{LiCl}-\mathrm{Li}_{2} \mathrm{O}$ may have resulted from the basic fluxing mechanism owing to the increased oxide ion $\mathrm{O}^{2-}\left(\mathrm{Li}_{2} \mathrm{O}\right)$ concentration $[47,48]$. Through the basic fluxing mechanism, in a molten salt with a high concentration of $\mathrm{O}^{2-}, \mathrm{O}^{2-}$ reacts with the oxide formed at the beginning of oxidation, and the oxide is dissolved in the molten salt and then reprecipitates as crystal grains of the oxide on the alloy surface [49]. As this phenomenon repeats itself, the porous film grows inside. In the case of a porous film, molten salt easily moves to the corrosion layer/alloy interface through the pores, and the corrosion layer grows from the interface toward the alloy as a product of the reaction with the alloy [50]. In the case where the Al-coated specimens were in the molten salt $\mathrm{LiCl}-(3$ and $8 \mathrm{wt} . \%) \mathrm{Li}_{2} \mathrm{O}$ for 72 and $168 \mathrm{~h}$, the fraction of the weight loss of the coated specimen to the bare specimen was approximately $60 \%$ for $3 \mathrm{wt} . \% \mathrm{Li}_{2} \mathrm{O}$ and $54 \%$ for $8 \mathrm{wt} . \% \mathrm{Li}_{2} \mathrm{O}$ at $72 \mathrm{~h}$, and approximately $38 \%$ for $3 \mathrm{wt} . \% \mathrm{Li}_{2} \mathrm{O}$ and $30 \%$ for $8 \mathrm{wt} . \% \mathrm{Li}_{2} \mathrm{O}$ at $168 \mathrm{~h}$. When the $\mathrm{Li}_{2} \mathrm{O}$ concentration was low, the fraction of the weight loss of the coated specimen to the bare specimen may have decreased owing to the protective film of the Al-based oxide formed on the surface of the coated specimen. However, as the $\mathrm{Li}_{2} \mathrm{O}$ concentration and the corrosion reaction time increased, the coating effect decreased. Considering that the oxide ion $\mathrm{O}^{2-}$ in the basic fluxing mechanism significantly participated in the corrosion reaction in the high-temperature molten salt, the increase in weight loss may have resulted from the increase in the oxide ion $\mathrm{O}^{2-}$ concentration due to the increased $\mathrm{Li}_{2} \mathrm{O}$ concentration, rather than the effect of the coating. 


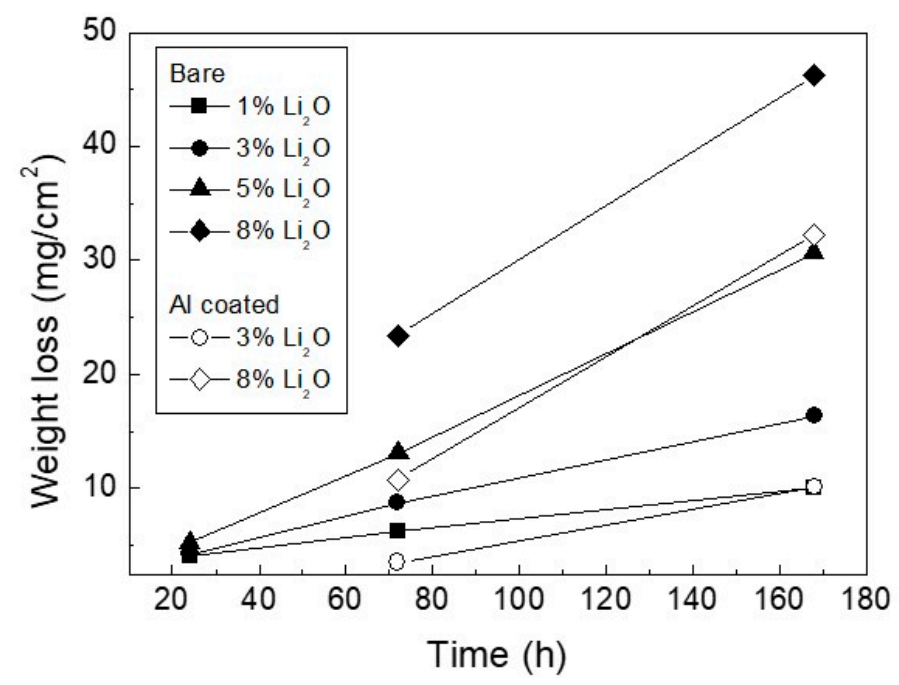

Figure 2. Weight loss of the bare (closed legends) and Al-coated (open legends) Haynes 263 specimens corroded at $650{ }^{\circ} \mathrm{C}$, as a function of time.

\subsection{Phase of Corrosion Products}

Figure 3 shows the XRD patterns of the corrosion products of the bare specimen corroded at $650{ }^{\circ} \mathrm{C}$ for $72 \mathrm{~h}$ in a molten salt of $\mathrm{LiCl}-(1,3$, and $5 \mathrm{wt} . \%) \mathrm{Li}_{2} \mathrm{O}$. The corrosion products were $\mathrm{Cr}_{2} \mathrm{O}_{3}, \mathrm{NiO}$, and $\mathrm{NiCr}_{2} \mathrm{O}_{4}$ for $1 \mathrm{wt} . \% \mathrm{Li}_{2} \mathrm{O}$ (Figure $3 \mathrm{a}$ ); $\mathrm{Li}(\mathrm{Ni}, \mathrm{Co}) \mathrm{O}_{2}$ and $\mathrm{Li}(\mathrm{Cr}, \mathrm{Al}) \mathrm{TiO}_{4}$ for $3 \% \mathrm{Li}_{2} \mathrm{O}$ (Figure $3 \mathrm{~b}$ ); and $\mathrm{Li}(\mathrm{Ni}, \mathrm{Co}) \mathrm{O}_{2}$ and $\mathrm{LiFeO}_{2}$ for $5 \% \mathrm{Li}_{2} \mathrm{O}$ (Figure 3c). Because $\mathrm{Li}_{2} \mathrm{O}$ is a strong basic oxide with properties similar to those of $\mathrm{Na}_{2} \mathrm{O}$, the phenomenon where corrosion is accelerated by $\mathrm{Li}_{2} \mathrm{O}$ can be explained by the basic fluxing mechanism suggested by Goebel et al. [48]. $\mathrm{Cr}_{2} \mathrm{O}_{3}$ and $\mathrm{NiO}$ were formed on the specimen surface at the beginning of the corrosion by the dissolved $\mathrm{O}$ present in the molten salt. The $\mathrm{Cr}_{2} \mathrm{O}_{3}$ and $\mathrm{NiO}$ reacted with the oxide ion $\mathrm{O}^{2-}\left(\mathrm{Li}_{2} \mathrm{O}\right)$ to form $\mathrm{CrO}_{4}{ }^{2-}\left(\mathrm{Li}_{2} \mathrm{CrO}_{4}\right)$ and $\mathrm{NiO}_{2}{ }^{2-}\left(\mathrm{Li}_{2} \mathrm{NiO}_{2}\right)$ and dissolved into the molten salt, which diffused outward and reprecipitated as $\mathrm{Cr}_{2} \mathrm{O}_{3}$ and $\mathrm{NiO}$ particles at the molten salt/atmosphere interface. For the reprecipitation of oxides suggested by Goebel et al. [48], a reduction in oxide ion $\mathrm{O}^{2-}$ activity from the specimen surface to the molten salt/atmosphere, i.e., a negative gradient of oxide solubility in the molten salt, is a prerequisite. Therefore, in the case of the $1 \mathrm{wt} . \%$ $\mathrm{Li}_{2} \mathrm{O}$, the corrosion products were $\mathrm{Cr}_{2} \mathrm{O}_{3}, \mathrm{NiO}$, and $\mathrm{NiCr}_{2} \mathrm{O}_{4}$. Spinel-type $\mathrm{NiCr}_{2} \mathrm{O}_{4}$ was formed by a solid-state reaction with the corresponding oxides $\left(\mathrm{NiO}\right.$ and $\left.\mathrm{Cr}_{2} \mathrm{O}_{3}\right)$ [51]. For $\mathrm{Li}_{2} \mathrm{O}$ concentrations of $3 \mathrm{wt} . \%$ or more, the absence of the reprecipitation of $\mathrm{Cr}_{2} \mathrm{O}_{3}$ and $\mathrm{NiO}$ may have occurred, resulting from a positive gradient of oxide solubility in the molten salt. Moreover, a corrosion product was formed by a basic fluxing reaction, in contrast to that observed in $1 \mathrm{wt} . \% \mathrm{Li}_{2} \mathrm{O}$. The physical properties of $\mathrm{Co}$, such as its crystal structure at a high temperature, atomic diameter, density, and melting point, are very similar to those of $\mathrm{Ni}$. Therefore, $\mathrm{Co}$ and Ni show similar diffusion behaviors, resulting in their coexistence on the surface oxide layer. The Ti content in the bare specimen was approximately $2.4 \%$, and the external diffusion rate of the more oxidative Ti at a high temperature was faster than that of $\mathrm{Cr}$ [52]. Thus, Ti diffused through the oxide and existed in the surface oxide layer. As the metal ions in the oxide can be ranked by their diffusion coefficients as $\mathrm{Fe}^{3+}>\mathrm{Fe}^{2+}>\mathrm{Ti}^{3+}$ $>\mathrm{Ni}^{2+}>\mathrm{Cr}^{3+}[51]$, the Fe ion diffused through the initially formed $\mathrm{Cr}$-oxide layer to form the corresponding oxide. $\mathrm{Li}(\mathrm{Ni}, \mathrm{Co}) \mathrm{O}_{2}, \mathrm{LiFeO}_{2}$, and $\mathrm{Li}(\mathrm{Cr}, \mathrm{Al}) \mathrm{TiO}_{4}$ were formed by the basic fluxing reaction. The examination of the formation process for these corrosion products revealed that the mechanism of formation differed depending on the concentration of $\mathrm{Li}_{2} \mathrm{O}$. 


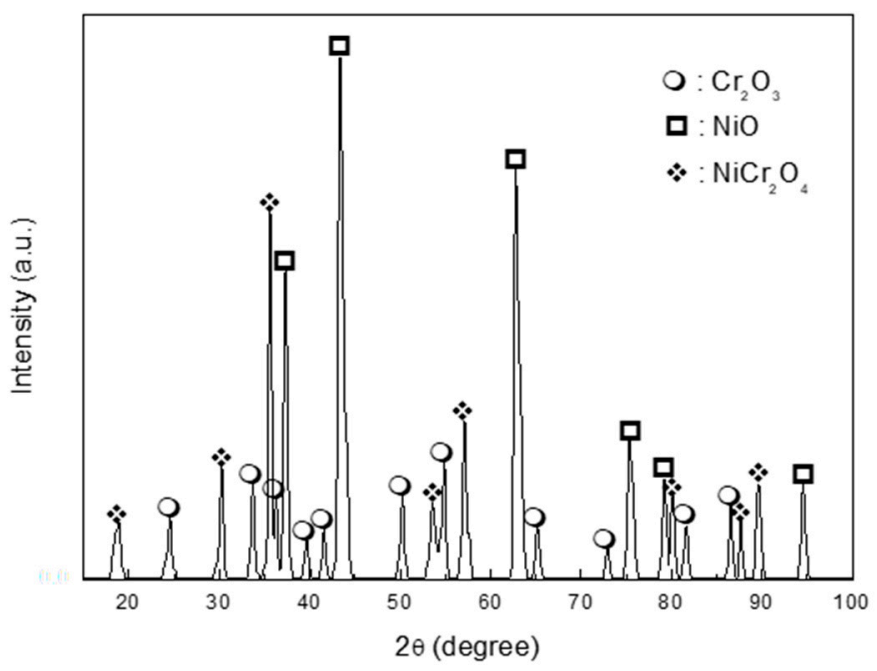

(a)

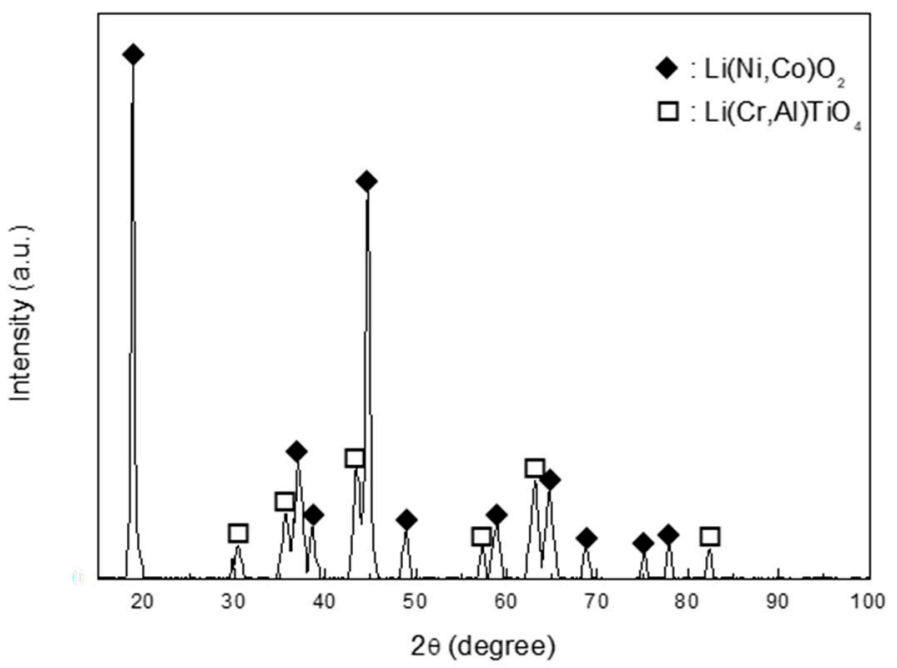

(b)

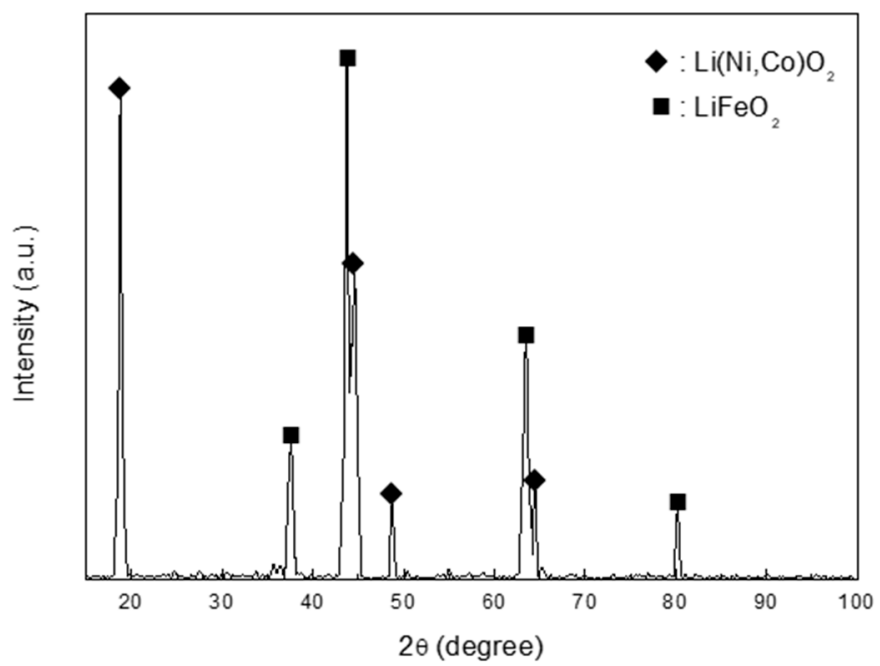

(c)

Figure 3. X-ray diffraction patterns of the corrosion products on bare specimens corroded in molten salt of $\mathrm{LiCl}-1(\mathbf{a}), 3$ (b), and $5 \mathrm{wt} . \% \mathrm{Li}_{2} \mathrm{O}(\mathbf{c})$ at $650{ }^{\circ} \mathrm{C}$ for $72 \mathrm{~h}$. 
Figure 4 shows the XRD patterns of the corrosion products of the coated specimen corroded at $650{ }^{\circ} \mathrm{C}$ for 72 and $168 \mathrm{~h}$ in a molten salt of $\mathrm{LiCl}-(3$ and $8 \mathrm{wt} . \%) \mathrm{Li}_{2} \mathrm{O}$. The corrosion products of the coated specimen were $\mathrm{LiAlO}_{2}, \mathrm{LiFeO}_{2}$, and $\mathrm{Li}(\mathrm{Ni}, \mathrm{Co}) \mathrm{O}_{2}$ for $72 \mathrm{~h}$ (Figure 4a) and $\mathrm{Li}(\mathrm{Ni}, \mathrm{Co}) \mathrm{O}_{2}, \mathrm{LiAlO}_{2}, \mathrm{LiTiO}_{2}$, and $\mathrm{LiFeO}_{2}$ for $168 \mathrm{~h}$ (Figure $4 \mathrm{~b}$ ) in a molten salt of $\mathrm{LiCl}-(3 \mathrm{wt} . \%) \mathrm{Li}_{2} \mathrm{O}$, and $\mathrm{LiAlO}_{2}$ and $\mathrm{LiFeO}_{2}$ for $72 \mathrm{~h}$ (Figure $4 \mathrm{c}$ ) and $\mathrm{Li}(\mathrm{Ni}, \mathrm{Co}) \mathrm{O}_{2}$ and $\mathrm{LiFeO}_{2}$ for $168 \mathrm{~h}$ (Figure $4 \mathrm{~d}$ ) in a molten salt of $\mathrm{LiCl}-(8 \mathrm{wt} . \%) \mathrm{Li}_{2} \mathrm{O}$. As shown in Figure 4, the protective role of the $\mathrm{LiAlO}_{2}$ generated by the basic fluxing reaction of $\mathrm{Al}$ oxide in the coating layer may have inhibited the external diffusion of elements of the base metal, thereby affecting the corrosion rate. However, as shown in Figure 2, it is believed that the increase in the corrosion rate was greatly influenced by the decrease in the protective role due to the dissolution of the $\mathrm{Al}$ oxide layer, which was caused by the increase in $\mathrm{Li}_{2} \mathrm{O}$ concentration and corrosion time. According to a report that discussed the change in the solubility of $\mathrm{Al}_{2} \mathrm{O}_{3}$ according to the $\mathrm{Na}_{2} \mathrm{O}$ concentration in a $\mathrm{Na}_{2} \mathrm{SO}_{4}$ electrolyte at $1200 \mathrm{~K}$, the solubility gradually decreases as the $\mathrm{Na}_{2} \mathrm{O}$ concentration increases, and the solubility increases rapidly after passing the critical point [49]. Based on this result, it is believed that an excessive increase in $\mathrm{Li}_{2} \mathrm{O}$ concentration in this study caused an increase in the solubility of $\mathrm{Al}_{2} \mathrm{O}_{3}$ due to a basic dissolution mechanism, leading to the destruction of the protective layer.

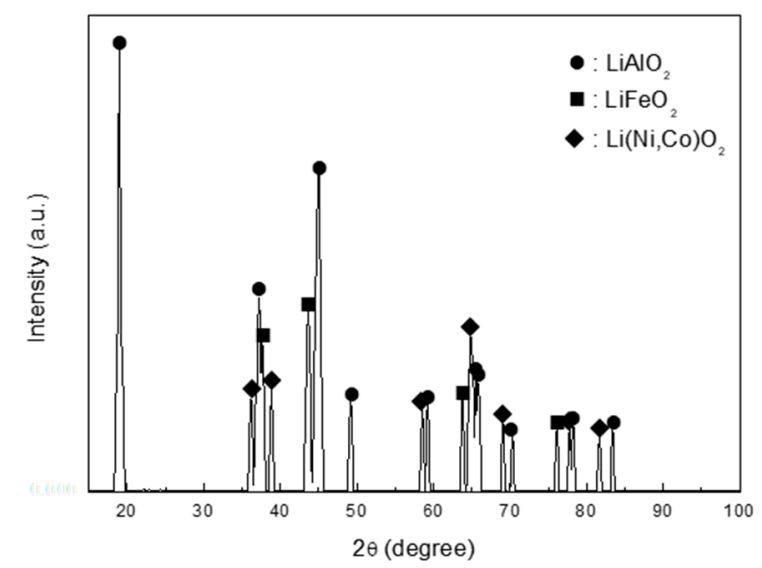

(a)

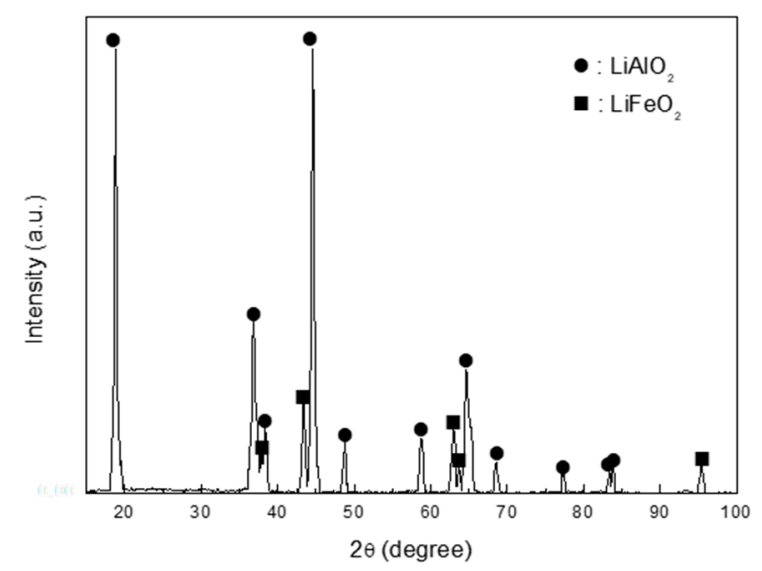

(c)

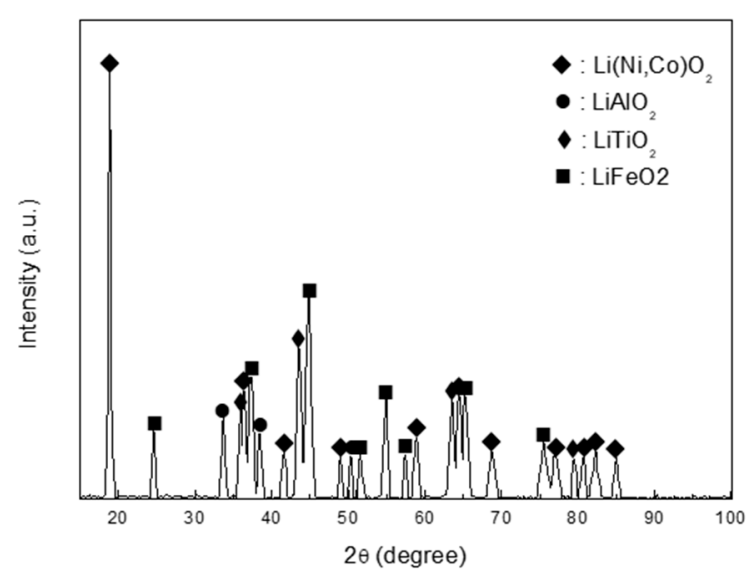

(b)

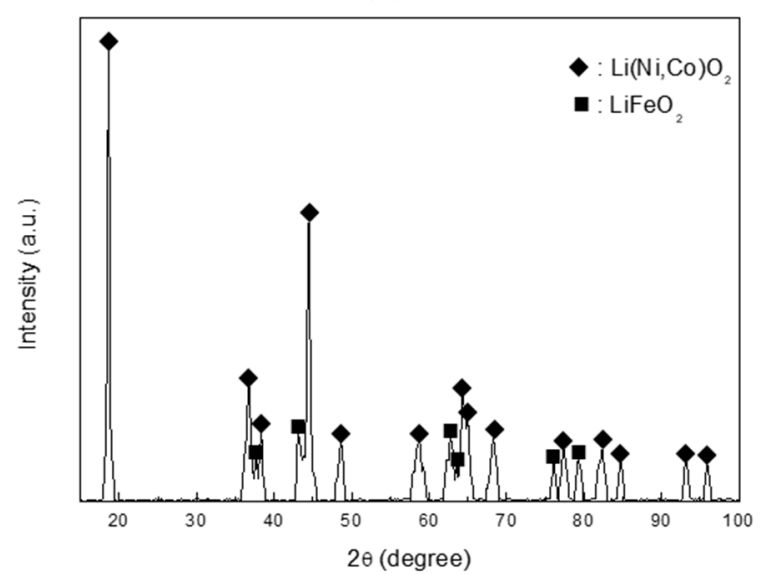

(d)

Figure 4. X-ray diffraction patterns of the corrosion products on Al-coated specimens corroded at $650{ }^{\circ} \mathrm{C}$ in molten salt of $\mathrm{LiCl}-3 \mathrm{wt} . \% \mathrm{Li}_{2} \mathrm{O}$ for 72 (a) and $168 \mathrm{~h}(\mathbf{b})$, and in molten salt of $\mathrm{LiCl}-8 \mathrm{wt} . \% \mathrm{Li}_{2} \mathrm{O}$ for 72 (c) and $168 \mathrm{~h}(\mathbf{d})$. 


\subsection{Corrosion Behavior}

Figure 5 shows the cross-sectional SEM image and elemental distribution of the bare specimen corroded at $650{ }^{\circ} \mathrm{C}$ for $72 \mathrm{~h}$ in a molten salt of $\mathrm{LiCl}-(1,3$, and $5 \mathrm{wt} . \%) \mathrm{Li}_{2} \mathrm{O}$. In the case of the $\mathrm{LiCl}-1 \% \mathrm{Li}_{2} \mathrm{O}$ salt, the corrosion layer was continuous, dense, and adherent, as shown in Figure 5a. The corresponding SEM image and elemental distribution show that the corrosion layer was mainly composed of $\mathrm{Cr}_{2} \mathrm{O}_{3}, \mathrm{NiO}$, and small amounts of $\mathrm{Al}, \mathrm{Fe}$, and Ti oxides. An intermediate layer rich in Ni-oxide scale formed close to the base metal. The oxygen active elements, such as $\mathrm{Al}$ and $\mathrm{Ti}$, were preferentially oxidized and participated in the corrosion layer [53]. Ni is an element that inhibits the internal diffusion of an oxygen ion by its accumulation at the oxide/oxide interface or beneath the oxide layers [54]. In this study, the enrichment of $\mathrm{Ni}$ in an internal corrosion layer was observed, and Ni was considered as a useful element for the enhancement of the corrosion resistance in an oxidative molten salt. As shown in Figure 2, the abovementioned features are considered to influence the corrosion rate. For $\mathrm{LiCl}-3 \% \mathrm{Li}_{2} \mathrm{O}$, as shown in Figure $5 \mathrm{~b}$, the corrosion layer consisted of $\mathrm{Cr}, \mathrm{Al}$, Ti-based oxides, and an Ni-Co-based complex oxide. The corrosion layer was continuous and dense. However, part of the corrosion layer peeled off, which may have resulted from damage during the polishing process, and a crack appeared between the corrosion layer and the substrate. As shown in Figure 2, molten salt easily diffused through the peeled parts and cracks, which may have affected the corrosion rate. In the case of $\mathrm{LiCl}-5 \% \mathrm{Li}_{2} \mathrm{O}$, the corrosion layer consisted of an Fe-based oxide and a Ni-Co-based complex oxide, as shown in Figure 5c. The corrosion layers and cracks appeared larger than those in Figure 5b, which had a significant influence on the corrosion rate, as shown in Figure 2.

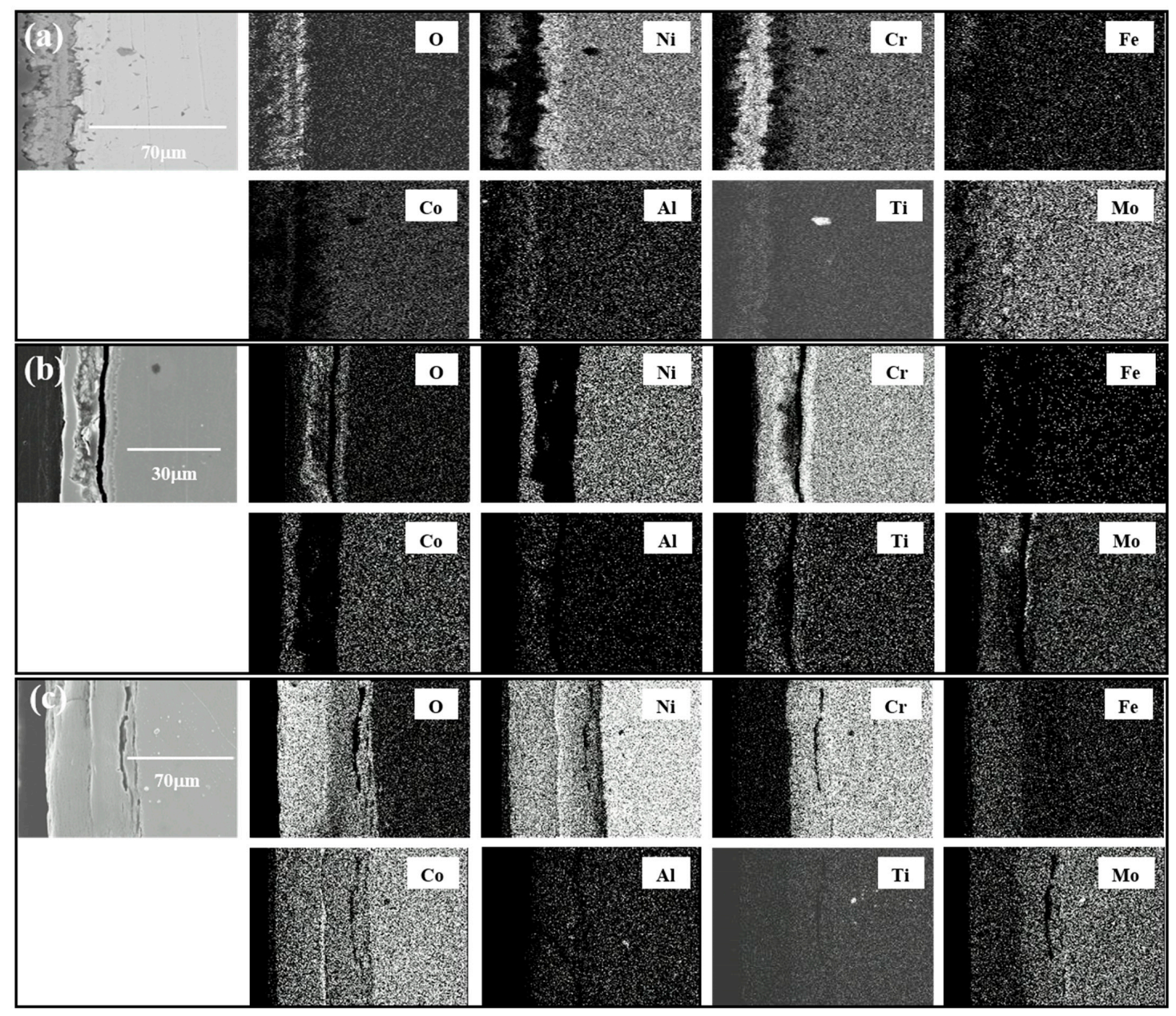

Figure 5. Cross-sectional SEM image and EDS elemental map of bare specimens corroded in $\mathrm{LiCl}-1 \mathrm{wt} . \% \mathrm{Li}_{2} \mathrm{O}(\mathbf{a}), \mathrm{LiCl}-3$ wt. $\% \mathrm{Li}_{2} \mathrm{O}(\mathbf{b})$, and $\mathrm{LiCl}-5 \mathrm{wt} . \% \mathrm{Li}_{2} \mathrm{O}(\mathbf{c})$ molten salt at $650{ }^{\circ} \mathrm{C}$ for $72 \mathrm{~h}$. 
Figure 6 shows the cross-sectional SEM image and EDS analysis results for the coated specimen corroded at $650{ }^{\circ} \mathrm{C}$ for $72 \mathrm{~h}$ in molten salts of $\mathrm{LiCl}-3$ (a) and $8 \mathrm{wt} . \% \mathrm{Li}_{2} \mathrm{O}$ (b). As shown in Figure 6a, the corrosion layer formed of $\mathrm{Al}$ oxide, Fe oxide, and $\mathrm{Ni}$-Co oxide appeared to be rough, while that composed of Fe-based and Ni-Co-based oxide is believed to have formed due to the diffusion coefficients of these elements being greater than those of the other elements; for example, $\mathrm{Fe}^{3+}>\mathrm{Ni}^{2+}\left(\mathrm{Co}^{2+}\right)>\mathrm{Cr}^{3+}$ [51]. Y is an element that promotes the oxidation of $\mathrm{Al}$ deposited on a base metal, densifies the Al-based oxide film, and improves adhesion; however, in this experiment, the $\mathrm{Y}$ deposited on the surface with a thickness of $0.3 \mu \mathrm{m}$ may have peeled off during the formation of the oxide layer or been removed during the dissolution of the formed oxide in the molten salt. Thus, the deposited $Y$ did not significantly contribute to the corrosion inhibition during the corrosion test. In addition, the internal corrosion layer appeared to be thin, which is thought to be due to the corrosion layer containing the Al-based oxide acting as a protective film inhibiting internal corrosion. Furthermore, there was a close correlation between the thin internal corrosion layer and the decrease in the corrosion rate, as shown in Figure 2 (open legends). In the case of $\mathrm{LiCl}-8 \mathrm{wt} . \% \mathrm{Li}_{2} \mathrm{O}$, as shown in Figure $6 \mathrm{~b}$, the corrosion layer was composed of Al-based oxide and Fe-based oxide, and the Fe-based oxide may have formed by the diffusion of $\mathrm{Fe}$, which has a higher diffusion coefficient than the other elements present in the base metal. In addition, the thickness of the corrosion layer shown in Figure 6b was less than that shown in Figure 6a; the large number of pores and cracks in the corrosion layer or the corrosion layer/substrate interface caused the large internal corrosion. These results are considered to have had a great influence on the corrosion rate, as shown in Figure 2.
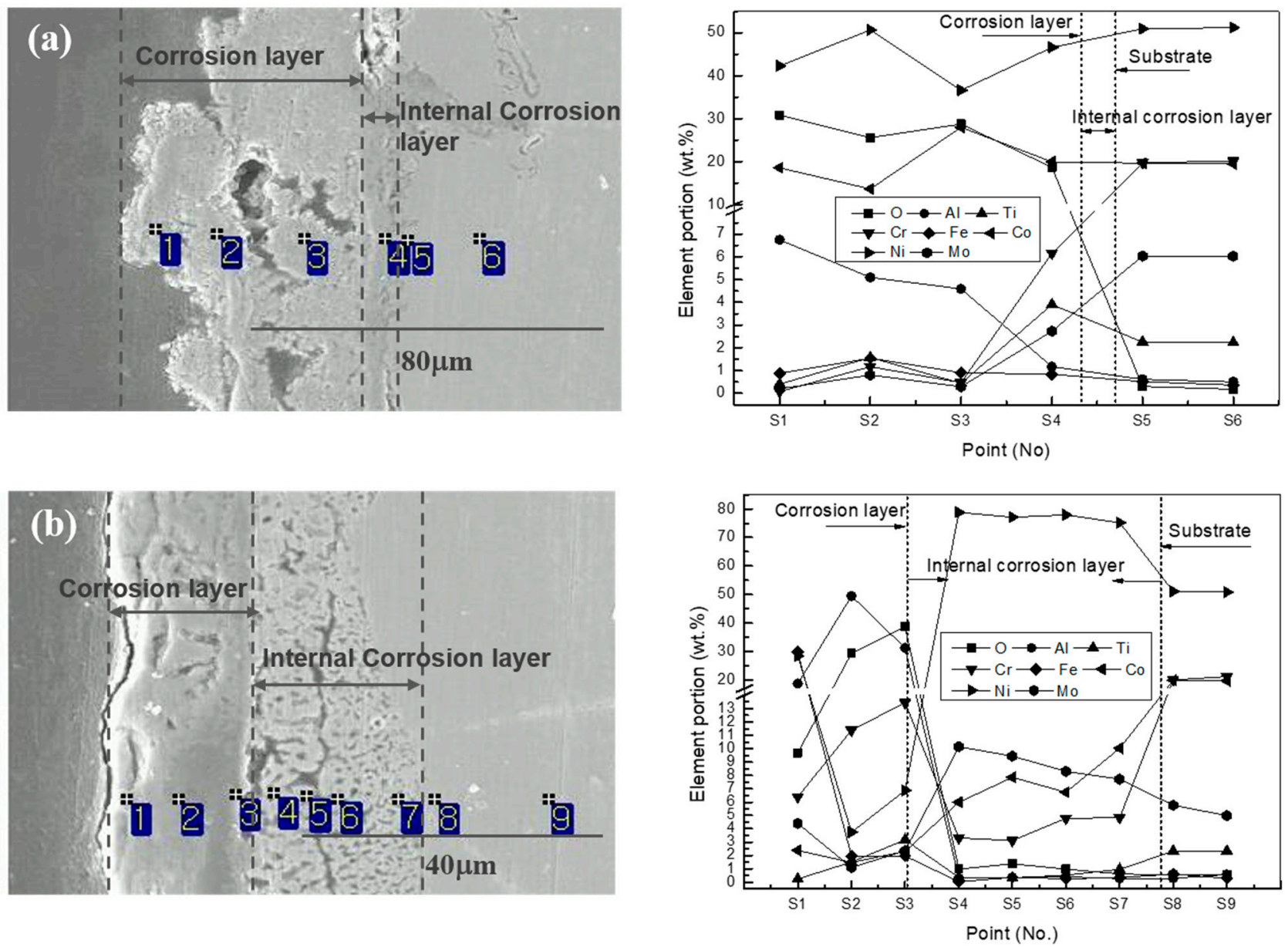

Figure 6. Cross-sectional SEM image and EDS point analysis results for Al-coated specimen corroded in $\mathrm{LiCl}-3 \mathrm{wt}$. $\% \mathrm{Li}_{2} \mathrm{O}$ (a) and $\mathrm{LiCl}-8 \mathrm{wt} . \% \mathrm{Li}_{2} \mathrm{O}(\mathbf{b})$ molten salt at $650{ }^{\circ} \mathrm{C}$ for $72 \mathrm{~h}$. 
Figure 7 shows the cross-sectional SEM images and elemental distribution of the coated specimen corroded at $650{ }^{\circ} \mathrm{C}$ for $168 \mathrm{~h}$ in molten salts of LiCl-3 wt.\% (a) and $8 \mathrm{wt} . \%$ $\mathrm{Li}_{2} \mathrm{O}(\mathrm{b})$. As shown in Figure 7a, the corrosion layer was formed of $\mathrm{Ni}, \mathrm{Co}, \mathrm{Cr}, \mathrm{Ti}$, and Fe-based oxides in addition to Al-based oxides, which are believed to have been generated due to the external diffusion of these elements in the base metal. Unlike that observed in Figure 6a, internal corrosion largely formed beneath the corrosion layer due to cracks generated at the corrosion layer/substrate interface. Moreover, considering the results of Figure 2 (open legends), as the reaction time increased, the weight loss increased due to the decrease in the protective role of the corrosion layer, including the Al-based oxide. In the case of $8 \mathrm{wt} . \% \mathrm{Li}_{2} \mathrm{O}$, as shown in Figure $7 \mathrm{~b}$, the corrosion layer was composed of $\mathrm{Ni}-\mathrm{Co}$-based oxide and Fe-based oxide, and Al-based oxide was not observed, as shown in the results of Figure $4 \mathrm{~d}$. When the $\mathrm{Li}_{2} \mathrm{O}$ concentration was high and the reaction time increased, the corrosion layer composed of $\mathrm{Ni}$-Co-based oxide and Fe-based oxide peeled and cracked, and internal corrosion proceeded greatly due to the deterioration of the protective performance of the corrosion layer. The peeling of the corrosion layer was caused by the internal stress and the difference in the thermal expansion coefficients of the oxides generated by the external diffusion of the internal elements of the base metal $[55,56]$.
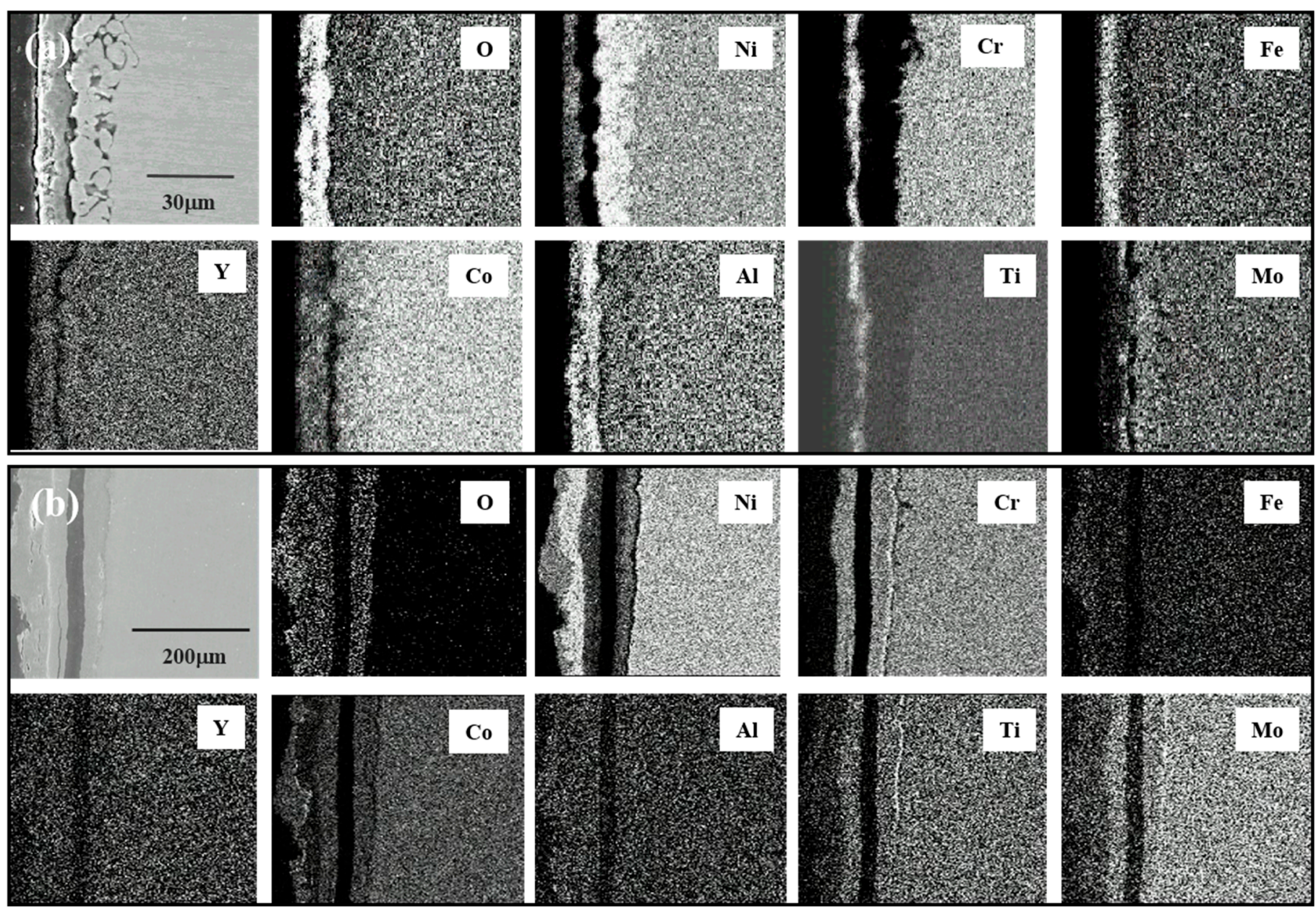

Figure 7. Cross-sectional SEM image and EDS elemental map of Al-coated specimen corroded in $\mathrm{LiCl}-3 \mathrm{wt} . \% \mathrm{Li}_{2} \mathrm{O}(\mathbf{a})$ and $\mathrm{LiCl}-8$ wt.\% $\mathrm{Li}_{2} \mathrm{O}\left(\right.$ b) molten salt at $650{ }^{\circ} \mathrm{C}$ for $168 \mathrm{~h}$. 


\section{Conclusions}

The following conclusions were drawn from the results of the study:

(1) The corrosion rate of the coated specimen decreased compared to that of the bare specimen. In the case of $3 \mathrm{wt} . \% \mathrm{Li}_{2} \mathrm{O}$, it decreased by approximately $60 \%$ at $72 \mathrm{~h}$ and approximately $38 \%$ at $168 \mathrm{~h}$. On the other hand, for the $8 \mathrm{wt} . \% \mathrm{Li}_{2} \mathrm{O}$, the corrosion rate decreased by approximately $54 \%$ at $72 \mathrm{~h}$ and $30 \%$ at $168 \mathrm{~h}$.

(2) In the molten salt of $\mathrm{LiCl}-\mathrm{Li}_{2} \mathrm{O}$, corrosion was carried out by the basic oxide ion $\mathrm{O}^{2-}$ by the basic fluxing mechanism, and the corrosion product depended on the activity of the oxide ion $\mathrm{O}^{2-}$.

(3) The corrosion products of the bare specimens at $72 \mathrm{~h}$ were $\mathrm{Cr}_{2} \mathrm{O}_{3}, \mathrm{NiO}$, and $\mathrm{NiCr}_{2} \mathrm{O}_{4}$ for 1 wt. $\% \mathrm{Li}_{2} \mathrm{O}$; $\mathrm{Li}(\mathrm{Ni}, \mathrm{Co}) \mathrm{O}_{2}$ and $\mathrm{Li}(\mathrm{Cr}, \mathrm{Al}) \mathrm{TiO}_{4}$ for 3 wt. $\% \mathrm{Li}_{2} \mathrm{O}$; and $\mathrm{Li}(\mathrm{Ni}, \mathrm{Co}) \mathrm{O}_{2}$ and $\mathrm{LiFeO}_{2}$ for $5 \mathrm{wt} . \% \mathrm{Li}_{2} \mathrm{O}$. However, the corrosion products of the coated specimens for 3 wt. $\% \mathrm{Li}_{2} \mathrm{O}$ showed $\mathrm{LiAlO}_{2}, \mathrm{LiFeO}_{2}$, and $\mathrm{Li}(\mathrm{Ni}, \mathrm{Co}) \mathrm{O}_{2}$ peaks for $72 \mathrm{~h}$ and $\mathrm{Li}(\mathrm{Ni}, \mathrm{Co}) \mathrm{O}_{2}$, $\mathrm{LiAlO}_{2}, \mathrm{LiTiO}_{2}$, and $\mathrm{LiFeO}_{2}$ peaks for $168 \mathrm{~h}$. In the case of $8 \mathrm{wt} . \% \mathrm{Li}_{2} \mathrm{O}, \mathrm{LiAlO}_{2}$ and $\mathrm{LiFeO}_{2}$ peaks for $72 \mathrm{~h}$ and $\mathrm{Li}(\mathrm{Ni}, \mathrm{Co}) \mathrm{O}_{2}$ and $\mathrm{LiFeO}_{2}$ peaks for $168 \mathrm{~h}$ were exhibited, respectively.

(4) The increase in the weight loss may have a higher dependence on the increase in the oxide ion $\mathrm{O}^{2-}$ concentration owing to the increase in the $\mathrm{Li}_{2} \mathrm{O}$ concentration than the reaction time.

(5) This coating was found to significantly increase the hot corrosion resistance of the structural material, improving its ability to handle high-temperature lithium molten salt under an oxidizing atmosphere. Thus, it is expected to be applicable to other processes that involve harsh conditions such as MCFC and waste incineration systems.

Author Contributions: Conceptualization, W.-B.K., S.-H.C., and J.-H.L.; methodology, W.-B.K. and J.H.L.; software, W.-S.C., and K.-S.L.; validation, W.-B.K. and J.-H.L.; formal analysis, W.-B.K., S.-H.C., and J.-H.L.; investigation, W.-B.K., S.-H.C., and J.-H.L.; resources, J.-H.L.; data curation, S.-H.C. and J.-H.L.; writing—original draft preparation, W.-B.K. and S.-H.C.; writing—review and editing, J.-H.L.; visualization, W.-B.K.; supervision, J.-H.L.; project administration, J.-H.L.; funding acquisition, J.-H.L. All authors have read and agreed to the published version of the manuscript.

Funding: This research was funded by Chungnam National University.

Institutional Review Board Statement: Not applicable.

Informed Consent Statement: Not applicable.

Data Availability Statement: The data are available from the corresponding author upon request.

Acknowledgments: This work was supported by the research fund of Chungnam National University.

Conflicts of Interest: The authors declare no conflict of interest.

\section{References}

1. Kumar, K.; Smith, N.D.; Lichtenstein, T.; Kim, H.J. Electrochemical Studies of Molten Sulfates in $\mathrm{LiCl}^{-} \mathrm{KCl}^{-\mathrm{Na}} 2 \mathrm{SO}_{4}$ at $700{ }^{\circ} \mathrm{C}$. Corros. Sci. 2018, 133, 17-24. [CrossRef]

2. Gonzalez-Rodriguez, J.G.; Haro, S.; Martinez-Villafañe, A.; Salinas-Bravo, V.M.; Porcayo-Calderon, J. Corrosion Performance of Heat Resistant Alloys in $\mathrm{Na}_{2} \mathrm{SO}_{4}-\mathrm{V}_{2} \mathrm{O}_{5}$ Molten Salts. Mater. Sci. Eng. A 2006, 435-436, 258-265. [CrossRef]

3. Gu, S.; Zhang, S.; Xu, D.; Li, W.; Yan, J. Evolution of Microstructure and Hot Corrosion Performance of $\mathrm{La}_{2} \mathrm{Hf}_{2} \mathrm{O}_{7} \mathrm{Ceramic}$ in Contact with Molten Sulfate-Vanadate Salt. Ceram. Int. 2018, 44, 2048-2057. [CrossRef]

4. Garip, Y.; Garip, Z.; Ozdemir, O. Prediction modeling of Type-I hot corrosion performance of Ti-Al-Mo-X (X=Cr, Mn) alloys in $(\mathrm{Na}, \mathrm{K})_{2} \mathrm{SO}_{4}$ molten salt mixture environment at $900{ }^{\circ} \mathrm{C}$. J. Alloys Compd. 2020, 843, 156010. [CrossRef]

5. Garip, Y.; Ozdemir, O. Corrosion Behavior of the Resistance Sintered TiAl Based Intermetallics Induced by Two Different Molten Salt Mixture. Corros. Sci. 2020, 174, 108819. [CrossRef]

6. Song, S.A.; Kim, H.T.; Kim, K.Y.; Lim, S.N.; Yoon, S.P.; Jang, S.C. Effect of $\mathrm{LiNO}_{2}$-Coated Cathode on Cell Performance in Molten Carbonate Fuel Cell. Int. J. Hydr. Energy 2019, 44, 12085-12093. [CrossRef]

7. Lee, M.H.; Lee, C.W.; Ham, H.C.; Han, J.H.; Yoon, S.P.; Lee, K.B. Mechanical Strength Improvement of Aluminum Foam-Reinforced Matrix for Molten Carbonate Fuel Cells. Int. J. Hydr. Energy 2017, 42, 16235-16243. [CrossRef]

8. Sher, F.; Al-Shara, N.K.; Iqbal, S.Z.; Jahan, Z.; Chen, G.Z. Enhancing Hydrogen Production From Steam Electrolysis in Molten Hydroxides via Selection of Non-Precious Metal Electrodes. Int. J. Hydr. Energy 2020, 45, 28260-28271. [CrossRef] 
9. Rehman, A.; Bidabadi, M.H.S.; Liang, Y.; Yu, Z.; Zhang, C.; Chen, H.; Yang, Z.-G. Hot Corrosion Behaviour of Yttrium and Aluminium Modified Wear Resistance Coating Alloy in Mixed Sulphate at $900{ }^{\circ}$ C. Corros. Sci. 2020, 165, 108369. [CrossRef]

10. Grosu, Y.; Anagnostopoulos, A.; Navarro, M.E.; Ding, Y.; Faik, A. Inhibiting Hot Corrosion of $\mathrm{Molten}^{\mathrm{Li}} \mathrm{CO}_{3}-\mathrm{Na}_{2} \mathrm{CO}_{3}-\mathrm{K}_{2} \mathrm{CO}_{3}$ Salt through Graphitization of Construction Materials for Concentrated Solar Powder. Sol. Energy Mater. Sol. Cells 2020, 215, 110650. [CrossRef]

11. Fernandez, A.G.; Cabeza, L.F. Corrosion Evaluation of Eutectic Chloride Molten Salt for New Generation of CSP Plants. Part 2: Materials Screening Performance. J. Energy Storage 2020, 29, 101381. [CrossRef]

12. Indacochea, J.E.; Smith, J.L.; Litko, K.R.; Karell, E.J.; Rarez, A.G. High-Temperature Oxidation and Corrosion of Structural Materials in Molten Chlorides. Oxid. Met. 2001, 55, 1-16. [CrossRef]

13. Chen, G.Z.; Fray, D.J.; Farthing, T.W. Direct Electrochemical Reduction of Titanium Dioxide to Titanium in Molten Calcium Chloride. Nature 2000, 407, 361-364. [CrossRef] [PubMed]

14. Ruh, A.; Spiegel, M. Thermodynamic and Kinetic Consideration on the Corrosion of $\mathrm{Fe}, \mathrm{Ni}$ and $\mathrm{Cr}$ Beneath a $\mathrm{Molten} \mathrm{KCl}-\mathrm{ZnCl}_{2}$ Mixture. Corros. Sci. 2006, 48, 679-695. [CrossRef]

15. Fang, Y.; Cui, X.; Jin, G.; Liu, E.; Zhang, D.; Wen, X.; Mi, Q. Microstructural Evolution and Hot Corrosion Behavior of $\mathrm{La}_{0.8} \mathrm{Ba}_{0.2} \mathrm{Ti}_{3-\delta}$-YSZ Double-Layer Thermal Barrier Coatings in $\mathrm{Na}_{2} \mathrm{SO}_{4}+\mathrm{V}_{2} \mathrm{O}_{5}$ Molten Salt at $900{ }^{\circ} \mathrm{C}$. Surf. Coat. Technol. 2020, 399, 126175. [CrossRef]

16. Zhang, S.; Li, H.; Jiang, Z.; Zhang, B.; Li, Z.; Wu, J.; Feng, H.; Zhu, H.; Duan, F. Chloride- and Sulphate-Induced Hot Corrosion Mechanism of Super Austenitic Stainless Steel S31254 Under Dry Gas Environment. Corros. Sci. 2020, 163, 108295. [CrossRef]

17. Zhuang, X.; Liu, W.; Xu, X. Hot Corrosion of Different Alloys in Chloride and Carbonate Molten-Salt Mixture Under Argon Atmosphere. Sol. Energy 2019, 189, 254-267. [CrossRef]

18. Zhu, B.; Lindbergh, G. Corrosion Behavior of High-Chromium Ferritic Steels in Molten Carbonate in Cathode Environment. Electrochim. Acta 2001, 46, 2593-2604. [CrossRef]

19. Lei, G.; Li, C.; Jiang, Z.; Huang, H. Irradiation Accelerated Fluoride Molten Salt Corrosion of Nickel-Based UNS N10003 Alloy Revealed by X-Ray Absorption Fine Structure. Corros. Sci. 2020, 165, 108408. [CrossRef]

20. Wu, Y.; Leng, B.; Li, X.; Jiang, L.; Ye, X.; Chen, Y.; Yang, X.; Li, Z.; Zhou, X. Corrosion Behavior of a Wear Resistant Co-Mo-Cr-Si Alloy in Molten Fluoride Salts. J. Nucl. Mater. 2020, 542, 152529. [CrossRef]

21. Doniger, W.H.; Falconer, C.; Elbakhshwan, M.; Britsch, K.; Couet, A.; Sridharan, K. Investigation of Impurity Driven Corrosion Behavior in Molten 2LiF-BeF 2 Salt. Corros. Sci. 2020, 174, 108823. [CrossRef]

22. McAlpine, S.W.; Skowronski, N.C.; Zhou, W.; Zheng, G.; Short, M.P. Corrosion of Commercial Alloys in FLiNaK Molten Salt Containing $\mathrm{EuF}_{3}$ and Simulant Fission Product Additives. J. Nucl. Mater. 2020, 532, 151994. [CrossRef]

23. Liu, Q.; Wang, Z.; Liu, W.; Yin, H.; Tang, Z.; Qian, Y. Ni-Mo-Cr Alloy Corrosion in Molten NaCl-KCl-MgCl 2 Salt and Vapour. Corros. Sci. 2021, 23, 180. [PubMed]

24. Li, X.L.; He, S.M.; Zhou, X.T.; Huai, P.; Li, Z.J.; Li, A.G.; Yu, X.H. High-Temperature Corrosion Behavior of Ni-16Mo-7Cr-4Fe Superalloy Containing Yttrium in Molten LiF-NaF-KF Salt. J. Nucl. Mater. 2015, 464, 342-345. [CrossRef]

25. Sidhu, T.S.; Prakash, S.; Agrawal, R.D. Evaluation of Hot Corrosion Resistance of HVOF Coatings on a Ni-Based Superalloy in Molten Salt Environment. Mater. Sci. Eng. A 2006, 430, 64-78. [CrossRef]

26. Wang, J.; Sun, J.; Zou, B.; Zhou, X.; Dong, S.; Li, L.; Jiang, J.; Deng, L.; Cao, X. Hot Corrosion Behavior of Nanostructured Zirconia in Molten $\mathrm{NaVO}_{3}$ Salt. Ceram. Int. 2017, 43, 10415-10427. [CrossRef]

27. Mohammadi Zahrani, E.; Alfantazi, A.M. High Temperature Corrosion and Electrochemical Behavior of INCONEL 625 Weld Overlay in $\mathrm{PbSO}_{4}-\mathrm{Pb}_{3} \mathrm{O} 4-\mathrm{PbCl}_{2}-\mathrm{CdO}-\mathrm{ZnO}$ Molten Salt Medium. Corros. Sci. 2014, 85, 60-76. [CrossRef]

28. Ai, H.; Ye, X.-X.; Jiang, L.; Leng, B.; Shen, M.; Li, Z.; Jia, Y.; Wang, J.-Q.; Zhou, X.; Xie, Y.; et al. On the Possibility of Severe Corrosion of a Ni-W-Cr Alloy in Fluoride Molten Salts at High Temperature. Corros. Sci. 2019, 149, 218-225. [CrossRef]

29. Wang, X.; Xin, L.; Wang, F.; Zhu, S.; Wei, H.; Wang, X. Influence of Sputtered Nanocrystalline Coating on Oxidation and Hot Corrosion of a Nickel-Based Superalloy M951. J. Mater. Sci. Technol. 2014, 30, 867-877. [CrossRef]

30. Mahini, S.; Asl, S.K.; Rabizadeh, T.; Aghajani, H. Effects of the Pack Al Content on the Microstructure and Hot Corrosion Behavior of Aluminide Coatings Applied on Inconel-600. Surf. Coat. Technol. 2020, 397, 125949. [CrossRef] [PubMed]

31. Cho, S.H.; Lee, S.K.; Kim, D.Y.; Lee, J.H.; Hur, J.M. Effects of Alloying Elements of Nickel-Based Alloys on the Hot-Corrosion Behavior in an Electrolytic Reduction Process. J. Alloys Compd. 2017, 695, 2878-2885. [CrossRef]

32. Du, K.; Yu, R.; Gao, M.; Chen, Z.; Mao, X.; Zhu, H.; Wang, D. Durability of Platinum Coating Anode in Molten Carbonate Electrolysis Cell. Corros. Sci. 2019, 153, 12-18. [CrossRef]

33. Kim, M.J.; Youn, J.Y.; Lim, J.H.; Eom, K.S.; Cho, E.A.; Kwon, H.S. Corrosion-Resistant Coating for Cathode Current Collector and Wet-Seal Area of Molten Carbonate Fuel Cells. Int. J. Hydr. Energy 2018, 43, 11363-11371. [CrossRef]

34. Bradshaw, A.; Simms, N.J.; Nicholls, J.R. Development of Hot Corrosion Resistant Coatings for Gas Turbines Burning Biomass and Waste Derived Fuel Gases. Surf. Coat. Technol. 2013, 216, 8-22. [CrossRef]

35. Bradshaw, A.; Simms, N.J.; Nicholls, J.R. Hot Corrosion Tests on Corrosion Resistant Coatings Developed for Gas Turbines Burning Biomass and Waste Derived Fuel Gases. Surf. Coat. Technol. 2013, 228, 248-257. [CrossRef]

36. Vakilifard, H.; Ghasemi, R.; Rahimipour, M. Hot Corrosion Behavior of Plasma-Sprayed Functionally Graded Thermal Barrier Coatings in the Presence of $\mathrm{Na}_{2} \mathrm{SO}_{4}+\mathrm{V}_{2} \mathrm{O}_{5}$ Molten Salt. Surf. Coat. Technol. 2017, 326, 238-246. [CrossRef] 
37. Gurrappa, I.; Sambasiva Rao, A. Thermal Barrier Coatings for Enhanced Efficiency of Gas Turbine Engines. Surf. Coat. Technol. 2006, 201, 3016-3029. [CrossRef]

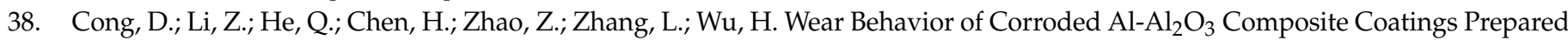
by Cold Spray. Surf. Coat. Technol. 2017, 326, 247-254. [CrossRef]

39. Strangman, T.; Raybould, D.; Jameel, A.; Baker, W. Damage Mechanisms, Life Prediction, and Development of EB-PVD Thermal Barrier Coatings for Turbine Airfoils. Surf. Coat. Technol. 2007, 202, 658-664. [CrossRef]

40. Zhang, Y.; Yang, Z.; Yu, Y.; Wen, B.; Liu, Y.; Qiu, M. Tunable Electromagnetic Interference Shielding Ability in a One-Dimensional Bagasse Fiber/Polyaniline Heterostructure. ACS Appl. Polym. Mater. 2019, 1, 737-745. [CrossRef]

41. Saini, P.; Choudhary, V.; Vijayan, N.; Kotnala, R.K. Improved Electromagnetic Interference Shielding Response of Poly(Aniline)Coated Fabrics Containing Dielectric and Magnetic Nanoparticles. J. Phys. Chem. C 2012, 116, 13403-13412. [CrossRef]

42. Allanore, A.; Yin, L.; Sadoway, D.R. A New Anode Material for Oxygen Evolution in Molten Oxide Electrolysis. Nature 2013, 497, 353-356. [CrossRef] [PubMed]

43. Adam, D. Aluminium Producers Promise a Cleaner Smelting Pot. Nature 2018, 557, 280.

44. Barthelemy, C.; Marmottant, A.; Laurent, V.; Bouvet, S.; Stabrowski, V.U.S. Cermet electrode material. Patent No. 0073109 A1, 15 March 2018.

45. Fernández, A.G.; Cabeza, L.F. Anodic Protection Assessment Using Alumina-Forming Alloys in Chloride Molten Salt for CSP, Plants. Coatings 2020, 10, 138. [CrossRef]

46. Jubeen, F.; Liaqat, A.; Sultan, M.; Iqbal, S.Z.; Sajid, I.; Sher, F. Green Synthesis and Biological Evaluation of novel 5-Fluorouracil Derivatives as Potent Anticancer Agents. Saudi Pharm. J. 2019, 27, 1164-1173. [CrossRef]

47. Shera, F.; Iqbal, S.Z.; Albazzaz, S.; Ali, U.; Mortari, D.A.; Rashid, T. Development of Biomass Derived Highly Porous Fast Adsorbents for Postcombustion $\mathrm{CO}_{2}$ Capture. Fuel 2020, 282, 118506. [CrossRef]

48. Goebel, J.A.; Pettit, F.S.; Goward, G.W. Mechanism for the Hot Corrosion of Nickel-Base Alloys. Met. Translator 1971, 2, $2875-2883$. [CrossRef]

49. Rapp, R.A. Hot Corrosion of Materials: A Fluxing Mechanism? Corros. Sci. 2002, 44, 209-221. [CrossRef]

50. Zeng, S.; Zhao, A.; Jiang, H.; Fan, X.; Duan, X.; Yan, X. Cyclic Oxidation Behavior of the Ti-6Al-4V Alloy. Oxid. Met. 2014, 81, 467-476. [CrossRef]

51. Harada, Y. High Temperature Oxidation and High Temperature Corrosion of Metallic Materials. I. High Temperature Oxidation. J. Jpn. Therm. Spray. Soc. 1996, 33, 128-134.

52. Izuta, H.; Komura, Y. High-Temperature Oxidation Behavior of Mechanically Alloyed Ni-Base Superalloys. J. Jpn. Inst. Met. 1994, 58, 1196-1205. [CrossRef]

53. Turkdogan, E.T. Physical Chemistry of High Temperature Technology; Academic Press: New York, NY, USA, 1980.

54. Cho, S.H.; Oh, S.C.; Park, S.B.; Ku, K.M.; Lee, J.H.; Hur, J.M.; Lee, H.S. High Temperature Corrosion Behavior of Ni-Based Alloys. Met. Mater. Int. 2012, 18, 939-949. [CrossRef]

55. Tawancy, H.M. High-Temperature Oxidation Behavior of a Wrought Ni-Cr-W-Mn-Si-La Alloy. Oxid. Met. 1996, 45, 323-348. [CrossRef]

56. Kim, I.H.; Jung, Y.I.; Choi, B.K.; Kim, H.G.; Jang, J.I. Corrosion and Oxidation Resistance Behaviors of Ta-Containing Low Alloying Zirconium. Met. Mater. Int. 2020. [CrossRef] 